\title{
THE ROLE OF LEADERSHIP AGILITY AND ORGANIZATIONAL COMMITMENT TOWARD ORGANIZATIONAL READINESS FOR CHANGES IN PUBLIC ISLAMIC UNIVERSITIES OF CENTRAL JAVA IN CONDITIONS OF VUCA ERA
}

\author{
Diharto Awan Kostrad \\ Faculty of Islamic Economic and Business, Institute Agama Islam Negeri Surakarta, \\ Indonesia \\ E-mail: awankostrad2018@gmail.com
}

\begin{abstract}
The VUCA era requires the role of leadership agility and organizational commitment for organizational readiness for change. For its readiness to change, the Public Islamic Universities in Central Java require leadership agility and organizational commitment from the academic community. This study aims to test the influence of Leadership Agility and Organizational Commitment toward Organizational Readiness for Change. This study is conducted in five Public Islamic Universities in Central Java, namely Institut Agama Islam Negeri (IAIN) Pekalongan, Universitas Islam Negeri (UIN) Semarang, Institut Agama Islam Negeri (IAIN) Salatiga, Institut Agama Islam Negeri (IAIN) Purwokerto, Institut Agama Islam Negeri (IAIN) Surakarta. These five universities have done the practice of leadership agility. The respondent of this study is 100 people, which taken using disporportional or disporportionate stratified random sampling method. This method is done by taking sample with not paying attention to the comparison of the number of members between subpopulation. The data analysis is performed using Partial Least Square. The result of this study shows that the variable of Leadership Agility has an influence toward Organizational Readiness for Change of 0.625 , while Organizational Commitment has an influence of 0.264.The result of this study is expected to be used in creating guidelines for Leadership Agility, building agile value, principles, and implementation or agile practice in Public Islamic Universities in Central Java.
\end{abstract}

\section{KEY WORDS}

Leadership agility, organizational commitment, organizational readiness for change, VUCA.

Speeding the development acceleration is one of the characteristics of the VUCA era that is called Volatility, which means progressive increase in the four dimensions of change, namely: type, speed, volume, and scale (http://sumberdaya.ristekdikti.go.id/index.php/2018/04/20/memaknai-kehadirandosen-asingke-indonesia/, accessed on April 24, 2018). Leading in the VUCA era nowadays (unstable, uncertain, complicated, and ambiguous) becomes increasingly difficult, since the VUCA era requires the ability of leaders to prepare the human resources they lead to be ready to face fast changes that are difficult to predict (Horney, et al., 2010).

The VUCA era requires Leadership Agility, which is the ability of a leader to dynamically feel and respond to changes in the business environment with focused, fast, and flexible actions. The organization must be prepared to change (Madsen, 2005).Agility and the ability to maneuver depend heavily on the agility that makes rapid changes in responding quickly. This especially happens on universities, since the process of managing the institutions in universities is very complex and diverse (Mukerjee, 2014).

Organizational readiness for change requires the role of organizational commitment (Eby, 2000). Organizational commitment that is shown in the involvement of human resources to change supports the organizational readiness for change (Weber \& Weber, 2001).

Public Islamic Universities in Central Java which includes of Institut Agama Islam Negeri (IAIN) Surakarta, Institut Agama Islam Negeri (IAIN) Salatiga, Institut Agama Islam Negeri (IAIN) Purwokerto, Universitas Islam Negeri (UIN) Walisongo Semarang, dan Institute 
Agama Islam Negeri (IAIN) Pekalonganrequire organizational readiness for change. Therefore, it needs leadership agility and organizational commitment from the academic community. It is very important to design and plan change in strategic management in Public Islamic Universities in Central Java.

\section{LITERATURE REVIEW}

The study conducted by Armenakis, et al. (1993) concluded that the readiness for change is related to beliefs, attitude, and intention of the member of organization to change. According to Backer, (1995), organizational readiness to change needs to pay attention to the dynamics of complex human resources. The involvement in planning for change affects their readiness for change. The study from Holt, et al (2007) showed that the instruments of organizational readiness for change are assessed from the characteristics of psychometric instrument. From the previous studies, the importance of correlating the role of leadership agility towards organizational readiness for change was not found. According to Lediju, (2016),leadership agility is the ability to lead effectively when there are rapid changes, uncertainty, increased complexity, and when considerations from various views and priorities for success are needed. The finding from showed how leaders in the public sector act. Leadership agility has a significant influence toward commitment and productivity of millennium organization. The study conducted by Joiner,\& Josephs, (2007) found that leadership agility is a leader who is skilled to implement four types of leadership agility that reinforce each other in high turbulent environments.

According, there is four types of leadership agility, namely: (1) Context-Setting Agility, which is the ability to determine the optimal scope of initiatives and clarify desired results; (2) Stakeholder Agility, leaders use "stakeholder" to identify an initiative, as well as understand and assess the extent to which their views and goals are aligned; (3)Creative Agility, which is the ability to found creative solutions; (4) Self-Leadership Agility, which is the agility to lead himself and mastering self-leadership, "If we ever hope to be effective leaders of others, we need first to be able to lead ourselves effectively."(Neck and Manz, 2012).

The finding fromVisagie and Steyn (2011) showed that affective and normative commitment has a positive relationship with readiness for change. The study from Holt, (2007) concluded that readiness for change is a multidimensional construct influenced by beliefs among employees, that: (a) they are able to apply the proposed changes, (b) proposed changes are appropriate for the organization, (c) leaders are committed to proposed changes (i.e. management support), and (d) proposed changes are beneficial to organizational members (i.e. personal valence).

Organizational commitment is a person's mindset towards the organization to what extent its own values and objectives are in accordance with those in the organization (Mowday et al, 1982). According toMathews and Shepherd (2002), organizational commitment is a strong belief and acceptance of employees towards organizational goals and values. With a strong organizational commitment, employees will strive to maintain the membership with the organization. Organizational commitment is the promise of an employee to be dedicated to his organization (Zangaro, 2001). The three main components of organizational commitment are: (1) Identification, connection, and pride of employees; (2) Engagement; and (3) Loyalty to institutions (Cook and Wall, 1980). The study from Madsen, at al (2005) found the relationship between organizational commitment and organizational readiness for change. When employees feel committed to their organization (loyal, engaged, and identified), the level of organizational readiness for change becomes better.

Organizational readiness for change refers to the commitment of change of every member of organization and applies it to organizational change (Weiner, 2009).

H1: Organizational Commitment has a significant influence toward Organizational Readiness for Change. Change.

H2: Leadership Agility has a significant influence toward Organizational Readiness for 


\section{METHODS OF RESEARCH}

The type of this study is quantitative research. The population of this study is the academic community of Public Islamic Universities in Central Java, namely Institut Agama Islam Negeri (IAIN) Surakarta, Institut Agama Islam Negeri (IAIN) Salatiga, Institut Agama Islam Negeri (IAIN) Purwokerto, Universitas Islam Negeri (UIN) Walisongo Semarang, and Institut Agama Islam Negeri (IAIN) Pekalongan.There are 100 respondents that become the sample of this study, which is taken using disproportional or disproportionate stratified random sampling. This method is carried out by taking samples without paying attention to the comparison of the number of members between subpopulation. The data analysis is performed with Partial Least Square.

\section{RESULTS AND DISCUSSION}

Table 1 until 4 describes that all items and variables have a good validity and reliability. Therefore, all questionnaire items have a good outer model.

Table 1 - Convergent Validity Test with 36 Indicators

\begin{tabular}{|c|c|c|c|}
\hline & Leadership Agility & Organizational Commitment & Organizational Readiness for Change \\
\hline $\mathrm{x} 1$ & 0.817 & & \\
\hline$x 2$ & 0.829 & & \\
\hline$x 4$ & 0.890 & & \\
\hline$x 5$ & 0.853 & & \\
\hline$x 6$ & 0.875 & & \\
\hline$\times 7$ & 0.854 & & \\
\hline$x 8$ & 0.861 & & \\
\hline$x 9$ & 0.862 & & \\
\hline $\mathrm{x} 10$ & 0.748 & & \\
\hline $\mathrm{x} 11$ & 0.743 & & \\
\hline $\mathrm{x} 12$ & 0.809 & & \\
\hline$x 13$ & 0.819 & & \\
\hline$x 16$ & & 0.771 & \\
\hline$x 17$ & & 0.720 & \\
\hline$x 18$ & & 0.833 & \\
\hline$x 19$ & & 0.815 & \\
\hline $\mathrm{x} 20$ & & 0.854 & \\
\hline$x 21$ & & 0.851 & \\
\hline $\mathrm{x} 22$ & & 0.790 & \\
\hline$x 23$ & & 0.813 & \\
\hline$x 24$ & & 0.782 & \\
\hline $\mathrm{y} 1$ & & & 0.763 \\
\hline $\mathrm{y} 2$ & & & 0.781 \\
\hline y3 & & & 0.754 \\
\hline $\mathrm{y} 4$ & & & 0.693 \\
\hline $\mathrm{y} 5$ & & & 0.706 \\
\hline y6 & & & 0.656 \\
\hline $\mathrm{y} 7$ & & & 0.729 \\
\hline y8 & & & 0.699 \\
\hline y9 & & & 0.743 \\
\hline $\mathrm{y} 10$ & & & 0.632 \\
\hline y11 & & & 0.762 \\
\hline $\mathrm{y} 12$ & & & 0.781 \\
\hline
\end{tabular}

Table 2 - Discriminant Validity Test

\begin{tabular}{|c|c|c|c|}
\hline $\mathrm{n} / \mathrm{n}$ & Leadership Agility & Organizational Commitment & Organizational Readiness for Change \\
\hline $\mathrm{x} 1$ & 0.817 & 0.735 & 0.729 \\
\hline $\mathrm{x} 2$ & 0.829 & 0.617 & 0.719 \\
\hline $\mathrm{x} 4$ & 0.890 & 0.683 & 0.775 \\
\hline $\mathrm{x} 5$ & 0.853 & 0.804 & 0.759 \\
\hline $\mathrm{x} 6$ & 0.875 & 0.710 & 0.817 \\
\hline
\end{tabular}




\begin{tabular}{|c|c|c|c|}
\hline $\mathrm{n} / \mathrm{n}$ & Leadership Agility & Organizational Commitment & Organizational Readiness for Change \\
\hline $\mathrm{x} 7$ & 0.854 & 0.690 & 0.759 \\
\hline $\mathrm{x} 8$ & 0.861 & 0.703 & 0.801 \\
\hline $\mathrm{x} 9$ & 0.862 & 0.670 & 0.770 \\
\hline $\mathrm{x} 10$ & 0.748 & 0.667 & 0.513 \\
\hline $\mathrm{x} 11$ & 0.743 & 0.738 & 0.522 \\
\hline $\mathrm{x} 12$ & 0.809 & 0.797 & 0.591 \\
\hline $\mathrm{x} 13$ & 0.819 & 0.777 & 0.754 \\
\hline $\mathrm{x} 16$ & 0.633 & 0.771 & 0.692 \\
\hline $\mathrm{x} 17$ & 0.545 & 0.720 & 0.597 \\
\hline $\mathrm{x} 18$ & 0.612 & 0.833 & 0.594 \\
\hline $\mathrm{x} 19$ & 0.596 & 0.815 & 0.645 \\
\hline $\mathrm{x} 20$ & 0.695 & 0.854 & 0.605 \\
\hline $\mathrm{x} 21$ & 0.662 & 0.852 & 0.649 \\
\hline $\mathrm{x} 22$ & 0.835 & 0.790 & 0.602 \\
\hline $\mathrm{x} 23$ & 0.813 & 0.816 & 0.578 \\
\hline $\mathrm{x} 24$ & 0.782 & 0.796 & 0.763 \\
\hline $\mathrm{y} 1$ & 0.641 & 0.726 & 0.781 \\
\hline $\mathrm{y} 2$ & 0.619 & 0.746 & 0.758 \\
\hline $\mathrm{y} 3$ & 0.615 & 0.754 & 0.690 \\
\hline $\mathrm{y} 4$ & 0.551 & 0.431 & 0.706 \\
\hline $\mathrm{y} 5$ & 0.619 & 0.513 & 0.656 \\
\hline $\mathrm{y} 6$ & 0.478 & 0.331 & 0.729 \\
\hline $\mathrm{y} 7$ & 0.696 & 0.575 & 0.699 \\
\hline $\mathrm{y} 8$ & 0.670 & 0.551 & 0.743 \\
\hline $\mathrm{y} 9$ & 0.608 & 0.581 & 0.632 \\
\hline $\mathrm{y} 10$ & 0.509 & 0.494 & 0.762 \\
\hline $\mathrm{y} 11$ & 0.643 & 0.552 & 0.762 \\
\hline $\mathrm{y} 12$ & 0.673 & 0.569 & \\
\hline & & & \\
\hline
\end{tabular}

Table 3 - Reliability Test

\begin{tabular}{|c|c|c|c|c|}
\hline $\mathrm{n} / \mathrm{n}$ & Cronbach's Alpha & rho_A & Composite Reliability & Average Variance Extracted (AVE) \\
\hline Leadership Agility & 0.931 & 0.933 & 0.943 & 0.647 \\
\hline $\begin{array}{c}\text { Organizational } \\
\text { Commitment }\end{array}$ & 0.959 & 0.965 & 0.964 & 0.691 \\
\hline $\begin{array}{c}\text { Organization } \\
\text { Readiness for Change }\end{array}$ & 0.918 & 0.922 & 0.93 & 0.527 \\
\hline
\end{tabular}

Table 4 - Model Accuracy Test

\begin{tabular}{|c|c|}
\hline R Square & R Square Adjusted \\
\hline 0.742 & 0.737 \\
\hline
\end{tabular}

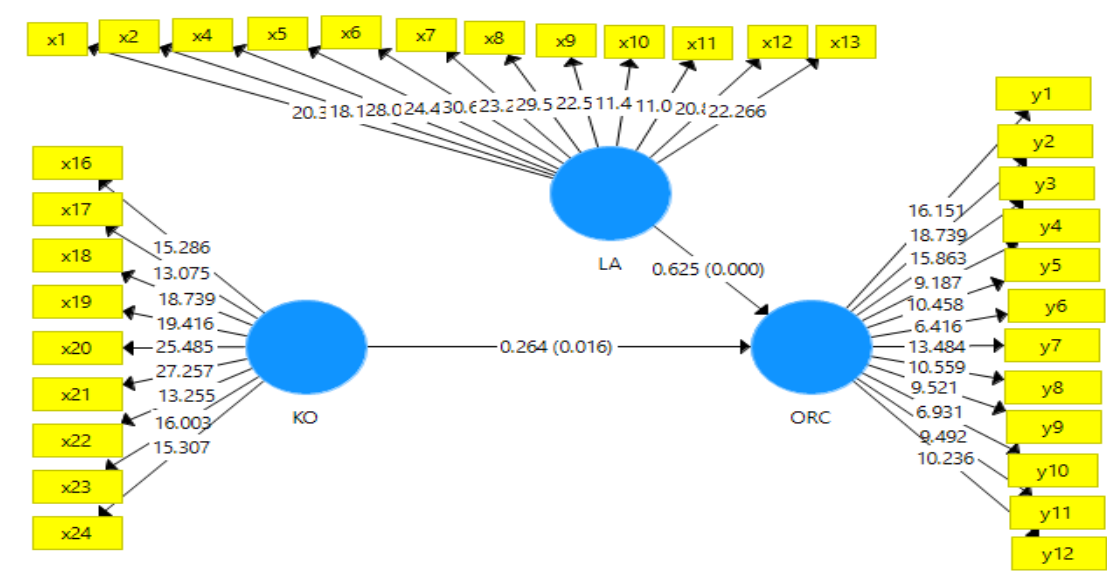

Figure 1 - Structural Model Between Latent Variables 
Table 5 - Hypothesis Test

\begin{tabular}{|c|c|c|c|c|c|c|}
\hline$n / n$ & $\begin{array}{c}\text { Original } \\
\text { Sample (O) }\end{array}$ & $\begin{array}{c}\text { Sample } \\
\text { Mean (M) }\end{array}$ & $\begin{array}{l}\text { Standard } \\
\text { Deviation } \\
\text { (STDEV) }\end{array}$ & $\begin{array}{l}\text { T Statistics } \\
(|\mathrm{O} / \mathrm{STDEV}|)\end{array}$ & $\begin{array}{c}\mathrm{P} \\
\text { Values }\end{array}$ & Decision \\
\hline $\begin{array}{c}\text { Organizational Commitment -> } \\
\text { Organizational Readiness for } \\
\text { Change }\end{array}$ & 0.264 & 0.271 & 0.109 & 2.412 & 0.016 & $\begin{array}{c}\mathrm{H} 1 . \\
\text { Accepted }\end{array}$ \\
\hline $\begin{array}{c}\text { Leadership Agility -> } \\
\text { Organizational Readiness for } \\
\text { Change (H2. Accepted) }\end{array}$ & 0.625 & 0.620 & 0.104 & 6.039 & 0.000 & $\begin{array}{c}\mathrm{H} 2 . \\
\text { Accepted }\end{array}$ \\
\hline
\end{tabular}

The result of the hypothesis test in this study can be seen from the $P$ value, which has the cutoff of $\leq 0.05$. In other words, if the $P$ value is greater than 0.05 , then the independent variable does not have an influence on the dependent variable. The analysis result of this study shows that the all of the $P$ value are below 0.05 , thus:

1. Organizational Commitment has a significant influence toward Organizational Readiness for Change;

2. Leadership Agility has a significant influence toward Organizational Readiness for Change.

An agile approach promotes agility or agile leadership to have an influence on organizational readiness for change which prioritizes serving leadership as a way to empower human resources. Serving leadership agility focuses on understanding, and refers to the needs and development of human resources to achieve the best performance.

The focus of leadership agility shifts from "managing coordination" to "facilitating cooperation". Leaders encourage everyone to be able to issue the ability to think and work as well as possible. Agile leaders encourage organizations to understand, be responsible for organizational performance, and create acceptable solutions. Agile leaders encourage collaborations and communications within the organization. They conduct collaboration through interactive meeting, informal dialogues, and knowledge sharing. Agile leaders become a bridge as well as coach, rather than making decisions whose responsibilities must be carried out by others.

Agile leaders closely monitor the processes that hinder organizational agility in the organizational readiness for change. The leaders in the Institut Agama Islam Negeri (IAIN) Surakarta, Institut Agama Islam Negeri (IAIN) Salatiga, Institut Agama Islam Negeri (IAIN) Purwokerto, Universitas Islam Negeri (UIN) Walisongo Semarang, and Institut Agama Islam Negeri (IAIN) Pekalongan have become agile leaders.

The indicators of leadership agility expertise are: 1) Skills in anticipating change; 2) Skills in generating self-confidence; 3) Skills in action; 4) Freeing thought; and 5) Results evaluation. Leadership agility behavior that carried out by leaders gives confidence that the organization is ready for change (organizational readiness for change) in facing the VUCA era. This is shown in the result of data processing which is obtained from several indicators, namely: 1) Feasibility; 2) Management Support; 3) Adoption of Changes; and 4) Personally Beneficial.

Organizational commitment in the academic community in five Public Islamic Universities in Central Java is enough to encourage the organizational readiness for change.

\section{CONCLUSION AND RECOMMENDATIONS}

Leadership Agility has a significant influence toward Organizational Readiness for Change, and the leaders in IAIN Pekalongan, UIN Semarang, IAIN Salatiga, IAIN Purwokerto, IAIN Surakarta has become agile leaders.

Organizational Commitment has a significant influence toward Organizational Readiness for Change. The organizational commitment in the academic community in five Public Islamic Universities in Central Java is good enough to encourage the organizational readiness for change.

This study shows that the leaders in Public Islamic Universities in Central Java have aligned the organization management with VUCA era. Further studies are required to explore 
further with qualitative research approach. The result of this study can be used to arrange guidelines for leadership agility, build agile values and principles, and implement the practice of leadership agility in Public Islamic Universities in Central Java.

\section{REFERENCES}

1. Armenakis, A. A., Harris, S. G., \& Mossholder, K. W. (1993). Creating readiness for organizational change. Human relations, 46(6), 681-703.

2. Backer, T. E. (1995). Assessing and enhancing readiness for change: Implications for technology transfer. In T. E. Backer, S. L. David, \& G. Soucy (Eds.), Reviewing the behavioral science knowledge base on technology transfer (pp. 21-41). Rockville, MD: National Institute on Drug Abuse.

3. Neck,C and Manz,C (2012). Mastering Self-Leadership: Empowering Yourself for Personal Excellence (6th ed.) ISBN: 978-0-13-275441-5 Publisher: Prentice Hall PTR Publication year: January 4, 2012

4. Cook, J., \& Wall, T. (1980). New work attitude measures of trust, organizational commitment and personal need non-fulfillment. Journal of Occupational Psychology, 53, 39-52.

5. Eby, L. T., Adams, D. M., Russell, J. E., \& Gaby, S. H. (2000). Perceptions of organizational readiness for change: Factors related to employees' reactions to the implementation of team-based selling. Human relations, 53(3), 419-442.

6. Holt, D. T., Armenakis, A. A., Feild, H. S., \& Harris, S. G. (2007). Readiness for organizational change: The systematic development of a scale. The Journal of applied behavioral science, 43(2), 232-255.

7. Horney, N., Pasmore, B., \& O'Shea, T. (2010). Leadership agility: A business imperative for a VUCA world. Human Resource Planning, 33(4), 34.

8. Joiner, B., \& Josephs, S. (2007). Developing agile leaders. Industrial and commercial training, 39(1), 35-42.

9. Lediju, T. (2016). Leadership agility in the public sector: Understanding the impact of public sector managers on the organizational commitment and performance of Millennial employees (Doctoral dissertation, Saybrook University).

10. Madsen, S. R., Miller, D., \& John, C. R. (2005). Readiness for organizational change: Do organizational commitment and social relationships in the workplace make a difference?. Human Resource Development Quarterly, 16(2), 213-234.

11. Mathews, B. P., \& Shepherd, J. L. (2002). Dimensionality of Cook and Wall's (1980) British Organizational Commitment scale. Journal of Occupational and Organizational Psychology, 75, 369-375.

12. Mukerjee, S. (2014). Agility: a crucial capability for universities in times of disruptive change and innovation. Australian Universities' Review, The, 56(1), 56.

13. Mowday, R. T., Porter, L. W., \& Steers, R. M. (1982). Employee-organization linkages:The psychology of commitment, absenteeism, and turnover. New York, NY: Academic.

14. Visagie, C. M., \& Steyn, C. (2011). Organisational commitment and responses to planned organisational change: An exploratory study. Southern African Business Review, 15(3), 98-121.

15. Weber, P. S., \& Weber, J. E. (2001). Changes in employee perceptions during organizational change. Leadership and Organization Development Journal, 22 (6), 291300.

16. Weiner, B. J. (2009). A theory of organizational readiness for change. Implementation science, 4(1), 67.

17. Zangaro, G. A. (2001). Organizational commitment: A concept analysis. Nursing Forum, $36(2), 14-22$.

18. https://kemenag.go.id/berita/read/506967/tidak-lagi-akses--sekjen-minta-ptkin-fokuspeningkatan-mutu di akses tanggal 24 April 2018 